\title{
MESQUITA, Léa Nilce (org.). Talupa/ Lixeratura: 30 anos. Belo Horizonte: Formato, 1998.
}

Edgard Pereira Universidade Federal de Minas Gerais

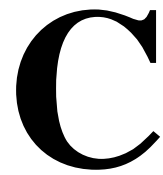

oordenei as ações acadêmicas relacionadas à publicação de Talupal Lixeratura: 30 anos, por encomenda da Faculdade de Letras da UFMG, entre os eventos comemorativos de seus trinta anos de fundação, em fins de 1998. Memória cultural tem-se revelado projeto de raras instituições, principalmente se não estão em epígrafe nomes de pavões ou peruas consagrados. Cabotinismo à parte, a revista lançada em edição despretensiosa e modesta surpreendeu os seus próprios editores, tal a acolhida e repercussão de que se revestiu. Entre patrulhas, tentativas de boicotes e críticas, fomos chamados de velhos poetas dos anos 60 pelo caderno cultural do Tempo; no Estado de Minas, José Bento
Teixeira de Salles referiu-se à publicação em artigo, salientando, entre outras coisas, o "evidente sentido de registrar a memória da Faculdade e da própria vida literária belo-horizontina na década de 60, quando foi de intensa efervescência o movimento cultural das vanguardas literárias da cidade" (18 dez 1998).

Como integrante de Talupa, não tenho o direito de me excluir das considerações gerais. Há trinta anos atrás, não éramos amigos nem mesmo conhecidos de curso secundário. Não morávamos na mesma rua, ou no mesmo bairro. Não viemos da mesma cidade. Não freqüentamos os mesmos colégios. Os que vieram do interior (como se deu comigo) ultrapassaram barreiras sólidas ou cruzaram dis- 
tâncias consideráveis. O que nos reuniu foram circunstâncias variadas, embora a motivação tenha sido uma só: a paixão pelas artes e pela literatura. Éramos jovens (entre dezoito e vinte anos) e tínhamos uma paixão ilimitada pela literatura. Apesar do contato recente, muitas outras circunstâncias nos aproximavam - a repressão política, a descoberta da metrópole, a afetividade sopesada, a solidariedade ideológica, a ilusão juvenil de tudo poder reinventar. A leitura em bloco dos textos recentemente reunidos o comprova.

Na década de 60, quase não havia TV e cada um de nós trazia em sua bagagem alguma experiência estética vivenciada, seja a participação em algum grupo amador de teatro de colégio ou do interior, seja a organização de algum tipo de jornal estudantil ou mesmo a pequena odisséia de já ter a custo ajuntado alguns livros ao escasso patrimônio individual. As dificuldades de acesso aos livros sempre foram imensas na cultura brasileira, ainda mais naquela época em que as livrarias eram raríssimas. O formato, a cor, a espessura dos livros, verdadeiros latifún- dios de emoções. Em alguns colégios (para não falar nos seminários, de onde alguns vieram) estudavam-se rudimentos de língua latina ou grega, juntamente com línguas modernas influentes, o que variava de uma região para outra: o espanhol, o francês, o inglês, o alemão.

A palavra acabou. O romance acabou. Bordões desse tipo, articulados ao famigerado salto epistemológico, eram comuns na imprensa especializada ou mesmo nas aulas. No meio de tanto apocalipse e escatologia, um grupo de jovens universitários se aglutinou em torno de uma publicação literária. Assim começou Talupa, cuja história detalhada acaba de ser contada por Léa Nilce Mesquita na revista em pauta. A falta de uma plataforma estética definida é sintomática da postura democrática e plural que presidia a escolha dos textos a serem publicados. Não cultivamos esse lado glamuroso dos movimentos literários. Todo poema pode ser um tapa ou um galope, mas antes de tudo precisa ser um poema. Além de participar das passeatas estudantis contra a situação política vigente (eram os anos rebeldes), o grupo 
de Talupa compreendeu que fazer aquele jornal era seu ato político mais legítimo, pela consciência de que a (desprestigiada) palavra nos salvava ou nos perdia. A paixão pela literatura saía pelos poros daqueles jovens ainda não entrados nos vinte anos e os fazia viver.

De repente a palavra geração fica incorporada a pequenas descobertas e conquistas. Pela primeira vez tive a experiência de conviver num espaço aberto de diálogo e confronto entre áreas de saber, tendências e sensibilidades. Alguns professores (agora foi revelado) como Maria Lúcia Lepecki, Luiz Carlos Alves e Maria Luiza Ramos se diziam surpreendidos com a qualidade dos textos que produzíamos. No nosso caso, a alegria de fazer Talupa, com sua criatividade multifacetada e suas ingenuidades. Como a corrida ao dicionário de um dos jovens autores, ao ouvir, no elevador da Faculdade, Maria Lúcia Lepecki se referir às possíveis influências surrealistas de seus textos.

A leitura completa do dossiê, tornada possível graças à compreensão da atual direção da Faculdade de Letras e ao apoio da Secretaria Estadual de Cultura, revela algumas obsessões da época, como a chegada do homem à lua (1968), o inconformismo diante da repressão política, o cotidiano captado pelo viés alegre ou ingênuo. Assim, o lirismo visceral de Magda Frediani nos leva a acompanhar o nascimento do bebê de cobalto, enquanto nas dobras da metalinguagem Léa Nilce acompanha a nave temp(l)o sideral/ que atravessa as portas do céu, Regina Sousa considera que todos se consomem entre umal picada e Marte e besitam entre a/ virgindade e a vagina de polietileno. Ronald Claver assinala de forma ácida que a palavra paz .../ apesar dos barulbos da guerra/ é silêncio da mais pura música ou que Tudo épossível// Impossível é calar no homem/ o vento da liberdade, ao mesmo tempo em que Filójardim assevera que - ofuzil que vela teu sonbo/ é temor que na carne te dói. O sofisticado discurso erótico de Marcantônio Guimarães, para não dizer ousado para a época - (Na primavera o amarelo é amarelo./ Ao companbeiro pergunto o porquê do campo aceso), o alcance reflexivo de 
Magda Frediani em "Depois de um sopro no fogo" - (estar como as brasas/ à espera/ extinta a chama/ dispersa a fumaça// (...) meu sonbo é essa casca exausta e nua/ que se desfaz em fogo/ $e$ renasce em poesia) - a espessa maturidade emotiva de alguns fragmentos de Lauro Machado Coelho (As folbas das árvores que vejo da janela do meu quarto, / mergulhadas no vento, convidam-me a desaparecer/ na floresta do universo, / a deitar-me à sombra de uma delas, bem frondosa,/ e ali viver para sempre como relva), a alegre ingenuidade de Léa Nilce em "A Andorinha" (...voe, andorinha, voe// volte para o ninbo// não encontra o caminho?/ esconda então neste ramo/ onde o poeta Drummond dependurou o paletó) - são elevados instantes de poesia raramente atingidos na poesia brasi- leira. Alguns textos, alguém dirá, são irremediavelmente datados. E daî? pergunto. Não sabemos desde Sartre e Croce que a literatura está inserida no contexto histórico, sendo a poesia, entre outras coisas, a mais fiel síntese do espírito humano de determinada época?

Este texto ficaria incompleto sem uma alusão à chama jamais apagada de Léa Nilce Mesquita, que possibilitou reunir todo o material, idealizou o formato e a modulação do que foi possível vir a lume. Do título à nota oportuna de Lázaro Barreto, reveladora da buliçosa cena cultural dos anos 70. Os grupos de poesia e ficção eram muitos e atuantes: Agora, de Divinópolis; Estaca, de Itapecerica; Ptyx e Frente, de Oliveira; Texto, de Belo Horizonte, entre outros. 